\title{
Small Scale Enterprises (SMEs) and Agricultural Transformation: The Nigeria Experience
}

\author{
Bello R. S. ${ }^{1,}$, , Bello M. B. ${ }^{2}$, Saidu M. J. ${ }^{3}$ \\ ${ }^{1}$ Department of Agriculture \& Bio-Environmental Engineering, Federal College of Agriculture Ishiagu, Nigeria \\ ${ }^{2}$ Department of Agricultural Economics and Management, Federal College of Agriculture, Ishiagu, Nigeria \\ ${ }^{3}$ Department of Agriculture \& Bio-Environmental Engineering, Federal College of Agriculture, Jalingo, Nigeria
}

\section{Email address:}

segemi2002@gmail.com (Bello R. S.),msjauro2020@gmail.com (Saidu M. J.)

\section{To cite this article:}

Bello R. S., Bello M. B., Saidu M. J.. Small Scale Enterprises (SMES) and Agricultural Transformation: The Nigeria Experience. Science Journal of Business and Management. Special Issue: Sustainable Entrepreneurial Developments in Agribusiness.

Vol. 3, No. 5-1, 2015, pp. 11-15. doi: 10.11648/j.sjbm.s.2015030501.13

\begin{abstract}
Nigerian agricultural sector has witnessed series of setbacks and interventions in its long history of development with minimal impacts from rural integration, development and promotion of small scale enterprises as well as private-public partnerships. This paper reviews the roadmap to Nigerian agricultural transformation in the face of government commitments, SMEs integration and domestic/foreign direct partnership in food security and sustainability.
\end{abstract}

Keywords: Agricultural Transformation, SMEs, Economy, Production, Investment

\section{Introduction}

In Nigeria, the highest percentage of the populace lives in the rural areas and is pre-occupied with agriculture at peasant level, where the bulk of the production comes from. However, the growing demands for increased agricultural production in Nigeria offers opportunities for farmers to relief the negative impact of traditional agricultural practices and underutilization of inputs in the new farming order of mechanization tagged 'precision agriculture' (Chinmay \& Subbs, 2000). One way by which this negative impact can be reversed is through the integration of the Small Scale Enterprises (SMEs) into agribusiness.

In the early and better part of 1960s, Nigerian economy was overwhelmed by a well-diversified agricultural sector, supporting over $75 \%$ of the population, with approximately $78 \%$ in food export and $94 \%$ of food supply to the rapidly growing population (World Bank, 1996; Abdulkareem, 2015). Nigeria small holder farmers constitute over $70 \%$ of the total people engaged in agricultural activities at small and medium scale levels. $70 \%$ of these farmers are not literate, $70 \%$ are of the age above 60 years and are mostly resident in the rural areas (National Agricultural Survey, 2001). The small and medium scale industries are seen as keys to integrated growth, alleviation of poverty and reduction of unemployment in the country (Aremu and Adeyemi, 2011).
However the discovery of oil in the oil-rich creeks of the country changed trend and made her become a monoeconomy nation solely dependent on the newly found oil. Today, Nigeria is about the ninth $\left(9^{\text {th }}\right)$ oil producing country in the world, yet could not fully combat food security situation in the country.

SMEs have been acknowledged to have huge potentials for sustainable development, contributing immensely to Gross Domestic Product (GDP), especially with full support on incentives, policies, programmes, financial and extension services. SMEs are found everywhere in the society including agriculture, spanning crop and animal production, processing and products marketing (Onwumere, 2008). These SMEs played vital roles in the economic development of nations and forms the bulk of business activities in growing economies like that of Nigeria (Emesowum et al., 2013). This paper focused on the role government and the SMEs in the development and transformation of agricultural production systems in a diversifying economy like Nigeria.

\section{Nigeria SMEs Outlook}

Nigeria SMEs are largely dominated by small and medium scale agro-based enterprises specializing in production of bulk commodities consumed in homes and industries and for export promotions, especially in cash crops and fruit 
production and processing. Nigeria is one of the leading countries in the production of agricultural products such as fruits, cassava, yam, cowpea and cocoa (Adewumi, 2008a) as well as fruits, leafy and root vegetables, grain legumes and animal products, of which the bulk is from the SMEs. These agricultural products are highly perishable and records of postharvest losses of these produce are very high with Nigeria having up to 50\% (Adewumi, 1998a). It has been reported that Nigerian agriculture suffers losses as much as $50 \%$ for vegetables, $30 \%$ for roots and tubers, and $20 \%$ for grains (FMARD, 2001). This trend is counterproductive and does not favour agro-based economic growth in a highly dependent agrarian economy.

\section{Government Agricultural Transformation Programme}

Since independence, successive governments in Nigeria have embarked on various agricultural production programmes and development plans targeted at improving agribusiness to date. The list are endless but include, the introduction of more modern agricultural practices through farm settlements, cooperative plantations, improved farm implements supplies and a greatly expanded agricultural extension services, establishment of National Accelerated Food Production Programme (NAFPP) in 1972, River Basin and Rural Development Authorities established in 1976, Operation feed the Nation (OFN) in 1977 and Green Revolution Programme inaugurated in 1980. The World Bank funded Agricultural Development projects, Rural Integrated Agricultural Development Programme (ADP), Agricultural Extension and Research Institutes were established in the mid-80s. These programmes sought to improve food and cash crop production in Nigeria, but available reports have shown that all these schemes have not yielded the expected results.

The current status of agriculture packaged by the present democratic dispensation introduced Agricultural Transformation Project (ATP) and various crops of comparative advantage are targeted under the transformation agenda to solve, in holistic and integrated manner, the constraints and weaknesses that have held down agricultural development in the country for a long time (Okafor and Malizu, 2013). The National Economic Transformation Agenda (NETA) of the federal government of Nigeria centers on diversification of economy from reliance on oil, assurance of food security, job creation and promoting agribusiness, attract private sector investment in agriculture, reduce postharvest losses, add value to local agricultural produce, development of rural infrastructure and enhancement of farmers' access to financial services and markets (FMARD, 2013). The agricultural transformation agenda (ATA) phase 1 was to enjoy the support of African Development Bank investment up to UA130.09 million, with UA98.82 million and UA0.21 million from ADF loan and grant, respectively. The government ATA programme seeks to grow and develop agriculture as a business and thereby create jobs, assure food security, promote private sector investments for wealth creation and maximize agriculture sector contribution to the country's economic growth (Okafor and Malizu, 2013).

\section{Nigeria Food Security and SMEs Sustainability Imperatives}

Food security and sustainability in agriculture in Nigeria where sufficient amount of safe and nutritious food to meet their dietary needs and food preferences for normal growth, development, and active healthy life (Hiroyuki and Salau, 2015) have become topical issues. Food security, both in terms of availability and access to food poses a challenge to rapidly growing population in environments of dwindling land and water resources. Farmers especially those producing fruits, vegetables (perishables) have emerged as a major economic activity in many places, but the challenge of preserving and storing these important products still remain untouched especially in the rural areas where the bulk of the production is experienced.

Despite the popularity of SMEs, its high demand, total production is grossly inadequate. This is because most entrepreneurs use obsolete tools and equipment and poor or non-preservative methods. World Bank survey (2000) showed that poor performance of SMEs in Nigeria was as a result of the public policy structure that did not provide the right incentives for growth. More than one third of the perishable food crops produced in the World are lost after harvest, due to poor or lack of preservative and storage methods. Most food crop products that are harvested seasonally are perishables and are subsequently subject to ripening, senescence, microbial and pest infestations, water loss, anatomical, morphological and compositional changes. This occurs because of the challenges faced by poor farmers in preservation and storage of these perishables. The development of adequate postharvest treatments for fresh food crop products, and their optimum use are of great necessity and economic importance. Adequate and appropriate postharvest treatments should reduce losses, and preserve perishable food product to meet consumer demands for constant availability and good quality supply throughout the year, thereby boosting food seasonality. Food must not only be produced, it must be delivered to the ultimate consumer in an acceptable form if it is to fulfill its nutritional purpose.

Rural communities are the main center of production of agricultural materials, which are the main raw materials for many industries (Adewumi, 2008b). It is therefore reasonable to develop feasible rural communities as industrial center to promote rural integration and development (Adewumi, 2008a). A number of major challenges facing the agricultural sector reflected through low productivity, and is worsened by poor preservative and storage methods, which have led to food insecurity in Nigeria. Agricultural products are highly perishable and must be evacuated from the farm as fast as 
possible and allow to cool in a shade or a ventilated store area. Basic infrastructures such as roads, communication network, power, water, store facilities etc. should be provided in rural centers. Electricity is a major sources of power required in processing and storage of agricultural products. Achieving food security in its totality, the challenges faced by the farmers in preserving and storing must be tackled. Promotion of appropriate technologies will be achieved through the adoption of improved, simple and affordable methods of preserving agricultural products in order to reduce postharvest losses thereby ensuring food security in Nigeria.

\section{Agricultural Transformation Outlook and its Gains}

Agricultural transformation agenda was able to chart a new course for agricultural development and the promotion of agribusiness and SMEs. The oil boom in the country has not benefited the people at large, hence a paradigm shift to reinvest in land and people through agriculture. Imo State has begun implementing the Imo State Oil Palm Development Programme (ISODEP) which targets to establish four million high yielding tenera palm trees by the year 2011(Bioenergy, 2007). The vision of ISODEP is to create an alternative economic revenue base and lay a solid foundation for agribusiness in Imo state as part of the millennium development goals critical objectives. The programme also seeks to reawaken the consciousness of Imo people to the nativity of palm tree and use the palm tree as a start-up tool for the clean and green initiative of the state government. Under the programme, the state government seeks to raise and distribute four million tenera oil palm for planting through small holder's management unit in every community in the state within a four-year period. The government is also set to produce palm oil cluster centers and establish semiautomated oil mills in each nucleus in the 27 local government areas in the state to significantly reduce poverty, enhance rural community development and create employment opportunities for the citizens.

Investment opportunities: There has been a rebirth of direct foreign and local investment in the agricultural input sectors of production agriculture such as domestic fertilizer industries, rapid knowledge transfer production along cassava production and processing chains, working with entrepreneur to develop out-grower program in production of high quality Nigerian rice and access to additional finance to expand operations. Table 1 represents the pay-off outlook on on-going government's new rice policy with 210,000 metric tons of new rice capacity (10\% of current imports) (FMARD, 2012).

Table 1. Pay-off outlook on government's 210,000 metric tons of new rice capacity.

\begin{tabular}{llll}
\hline Company & State & Capacity MT/Yr & Status \\
\hline Atahi rice & Jigawa & 60,000 & In process \\
Ashi feeds & Benue & 10,000 & Started post June 2012 \\
Mikap & Benue & 10,000 & Started post June 2012 \\
Dominion & Taraba & 10,000 & In process \\
Gauri & Bauchi & 10,000 & In process \\
Clysters & Nasarawa & 10,000 & In process \\
Umza & Kano & 60,000 & New line started post June 2012 \\
Omor & Anambra & 10,000 & In process \\
Kare Hi-Tech & Zamfara & 9,000 & In process \\
Oni-MP farms & Cross River & 8,000 & In process \\
Al-Uma & Taraba & 8,000 & In process \\
Ebony agro & Ebonyi & 30,000 & Started post June 2012 \\
Lagos & Lagos & 5,000 & Started post June 2012 \\
\hline
\end{tabular}

Source: FMARD, 2012

Urbanization: This transformation has also resulted in rapid urbanization, rising middle class incomes, supermarkets and demand for "ease to prepare foods" and investment opportunities in food processing and manufacturing from local staple crops from staple crop processing zones (SCPZ) such as maize, soybeans, rice (Kadawa valley, Kano; Bidda-Badeggi, Niger; Ikwo, Ebonyi; Gassol, Taraba and Sokoto/Kebbi respectively), yams, cassava, sweet potatoes, sorghum with additional SCPZ sites designated to cover horticultural crops (Kadawa Valley, Kano (tomato); Wanunne, Benue (Citrus, tomato \& mango); Calabar, Cross-river (pineapple), livestock, oil palm, cotton, cocoa etc.

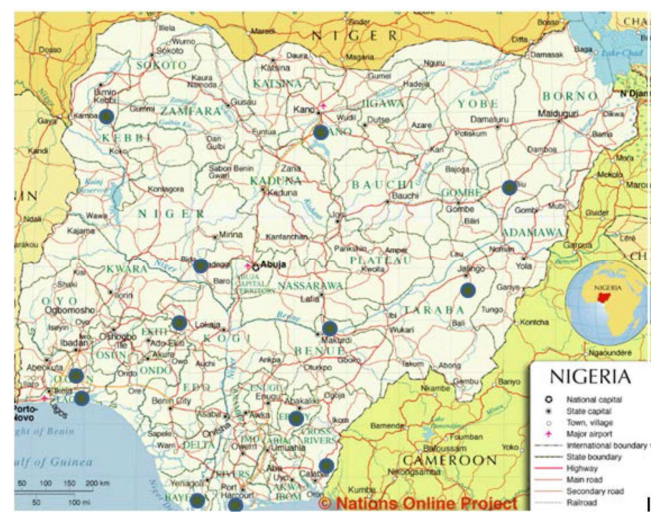

Figure 1. 14 Staple crop processing zone sites around the country (FMARD, 2013). 
Direct returns on agricultural investment: Agricultural transformation agenda (ATA has clearly showed that there can be significant direct returns on agricultural investment with total commitment to the development and supports to development of vital agricultural production activities. This is evident from the modelled investment themes and regimented startup capital investments on fixed assets targeted at fixed payback period. Table 2 shows the sampled rate of returns on agricultural investments in production and processing of some agricultural crops.

Table 2. Sample rates of returns to agricultural investments in Nigeria.

\begin{tabular}{|c|c|c|c|c|}
\hline Crop & Modeled investment theme & Startup capital (fixed assets) & IRR & $\begin{array}{l}\text { Payback } \\
\text { period }\end{array}$ \\
\hline Tomato & Tomato paste and related products plant to replace imported Chinese paste & $\$ 3.9 \mathrm{M}$ for plant with 15,000 tons/annum & $20 \%$ & 4years \\
\hline Cassava & Cassava chips for export to Northeast Asia & $\$ 3.5 \mathrm{M}$ for plant with 115,000 tons/annum plant & $19 \%$ & 4.5years \\
\hline Cotton & Cotton production and ginning into lint for export and domestic markets & $\$ 3.2 \mathrm{M}$ for a 30,000 ton /annum ginnery & $20 \%$ & 3.5years \\
\hline Maize & Processing into animal feed to serve fast growing livestock market & $\$ 3.5 \mathrm{M}$ for a 50,000 ton/annum plant & $30 \%$ & $\sim 3.6$ years \\
\hline Rice & Rice production and milling serving large domestic demand & $\$ 6.1 \mathrm{M}$ on a 45,000 ton/annum rice mill & $33 \%$ & 3.5 years \\
\hline $\begin{array}{l}\text { Soya } \\
\text { beans }\end{array}$ & $\begin{array}{l}\text { Processing into animal feeds, industrial supplements and oil for domestic } \\
\text { markets }\end{array}$ & $\$ 10 \mathrm{M}$ on a 100,000 ton plant & $106 \%$ & 4.5 years \\
\hline
\end{tabular}

Source: Monitor Analysis; Interviews with Processors; NIRSAL Analysis (FMARD, 2012)

Support on zero import duty on agricultural machinery: ATA support for zero $(0 \%)$ import duty on agricultural implements and machinery offers a relief to small scale farm holders who requires special package on tractor and equipment ownership (FMARD, 2012). A more transparent look at suggested public-private partnership tractorization scheme (PPPTS) and clustered farm settlement schemes could offer relief to failed government tractorization scheme. The import duty free on agricultural machinery and new fiscal incentives to encourage domestic import substitution are supportive of investors' promotion in agricultural production.

\section{Conclusions}

The climax of farming is the harvest of the good quantity, quality products. In order to reduce post-harvest losses of products, adequate preservation technologies should be adopted by the farmers. Moreover, government should established more agro-processing centers/storage facilities in rural areas with high capacity production of agricultural produce, and basic infrastructures should be provided in areas where the bulk of the produce comes from, so that food security should be assured. Also, to achieve this, policies that would enhance the access to micro credit facilities through other government and non-governmental organization apart from the Nigerian banks by these enterprises should be advocated for with little or without interest rate. And SMEs should be encouraged to form cooperative groups within their catchment areas, so as to place them more favourably in capital acquisition while strengthening extension services in the area. The neglect of these major factors will militate against agricultural transformation and rural agricultural development in Nigeria.

\section{References}

[1] Abdulkareem Ibrahim Babatunde, 2015. Role of information and communication technology in sustainable agriculture in Nigeria. Paper presented by the Director Engineering Services
Sub-Programme, Edo State agricultural Development Programme (EDADP), Benin City, Edo State. Nigeria. Pg 1-9 Date modified 14-06-2015

[2] Adewumi, B. A. (2008a): Fruit Production and Processing. Option for Rural Industrialization and Poverty Alleviation in Nigeria. Book Project of the Alexander Vom Itumboldt Foundation Pg 43-53

[3] Adewumi, B. A. (2008b): Collaborative Research in the Development of food machinery for Africa. Proceeding of the conference on collaboration Research for Technical development. Organized by Makerere University, Kampala, Uganda Pg 10.

[4] Aremu, M. A. and S. L. Adeyemi (2011): Small and medium scale enterprises as a survival strategy for employment generation in Nigeria. Journal of sustainable development. Vol. 4 no. 1.

[5] Bioenergy, 2007. Nigeria's Imo state launches large palm programme to shake off oil curse. http://news.mongabay.com/bioenergy/2007/12/nigerias-imostate-launches-large-palm.html

[6] Emesowum, C. E.; J. A. Mbanasor and S. A. Olayimola (2013): Analysis of factors affecting performance of agribusiness-SMEs in Imo State, Nigeria: policy issues for agricultural transformation. Proc. of the $47^{\text {th }}$ Annual Conf. of agricultural society of Nigeria, Ibadan 2013. Pp 518-521.

[7] FMARD (2001): Federal Ministry of Agriculture and Rural Development. New Agricultural Policy Thrust. http/www.fao.org/docrep/004/AC301e03.htm15/org

[8] FMARD, 2012. Minister of Agriculture and Rural Development. Agricultural Transformation Agenda: Repositioning agriculture to drive Nigeria's economy. Paper presented by Dr. Akinwumi Adesina, Honourable 20121205120841-agri2012-special_session-tony_bellomin_agric_nigeria.pdf

[9] FMARD, 2013. Agricultural Transformation Agenda Support Program - Phase 1 (ATASP-1). Strategic Environmental and Social Assessment (SESA-Summary). Nigerian Federal Ministry of Agriculture and Rural Development (FMARD)

[10] Hiroyuki Takeshima and Sheu Salau, 2015. Agricultural Mechanization and the Smallholder Farmers in Nigeria. Nigeria Strategy Support Program. International Food Policy Research Institute (IFFPRI) Policy Note No. 22. Pg. 1-5 
[11] Okafor, G. O. \& Malizu, C. F., 2013. New Media and Sustainable Agricultural Development in Nigeria. New Media and Mass Communication Vol.20. PP 1-9. ISSN 2224-3267 (Paper) ISSN 2224-3275 (Online) www.iiste.org
[12] Onwumere, J. (2008): Policy issues in enhancing the output of Agribusiness of small and medium scale. Piggery enterprises (AGRI-SMEs) in Abia State. Journal of Agricultural Extension. Vol. 12 (2). 